\title{
Macroanatomical and morphometric study on the skull bones of Aksaray Malakli dogs
}

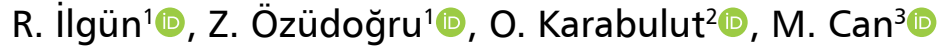 \\ 'Department of Anatomy, Faculty of Veterinary Medicine, Aksaray University, Aksaray, Turkey \\ 2Department of Biometrics, Faculty of Veterinary Medicine, Aksaray University, Aksaray, Turkey \\ ${ }^{3}$ Department of Anatomy, Faculty of Veterinary Medicine, Balıkesir University, Balıkesir, Turkey
}

[Received: 19 December 2020; Accepted: 11 January 2021; Early publication date: 9 February 2021]

\begin{abstract}
Background: The skull is an important anatomical structure to discern dog breeds and wolves from dogs. For this purpose, skull morphology and some morphometric measurements of Malakli dogs, a local breed in the Aksaray region, were examined. Materials and methods: Thirty-two distances were measured and seven ratios calculated in nine skulls of adult dogs. In our study, different morphological features and statistical findings that were not revealed by taking measurements from 32 distinct anatomical points of Aksaray Malakli dog skull bones were determined in accordance with the literature.

Results: Processus zygomaticus was found to be long and pointed in the Aksaray Malakli dogs. The results of morphometric analysis were as follows: facial index value $107.68 \pm 4.98$, nasal index value $19.61 \pm 3.25$, cranial index value $56.17 \pm$ \pm 2.52 , basal index value $30.57 \pm 1.30$, skull index $54.68 \pm 3.01$, palatal index I value $56.76 \pm 1.89$ and palatal index I/ value $59.83 \pm 2.23$

Conclusions: It can be concluded form the present investigation that the neurocranium length, facial index, cranial index, basal index, skull index, and palatal index values were statistically different from other dog breeds. (Folia Morphol 2022; 81, 1: 157-163)
\end{abstract}

Key words: neuroanatomy, macroanatomy, morphometric, cranial index

\section{INTRODUCTION}

Aksaray Malakli dogs are large guarding dogs and their name comes from the Aksaray region in Turkey where they come from. According to the findings in the genetic studies on dog breeds, it is reported that mastiff-type dogs may be a different breed due to their genetic similarity to Akbaş, Kars and Kangal shepherd dogs [2-4]. Aksaray Malakli dog has a grey-coloured, large body and drooping lips. The paws are bigger and thicker than the Kangal dog, which breeders mostly compare. However, it is reported that Aksaray Malakli dog is not preferred in herd management, because it is not resistant to cold climate and because of the saggy nature of its lips; it drains the mouth, salivates while drinking water and it is tired quickly after guarding the herd $[2,3,5,18$, $26,27]$. The skull is an important anatomical structure to discern dog breeds $[1,9,11,12,28]$, Kangal and Malakli dogs [10, 18, 21], Tarsus Çatalburun dog [17], German wolfdog [19, 20], and grey wolf [14]. It has been found that there are many studies on skull morphology and morphometry in lynx [7], red fox [22], vulpes [25] and golden jackal [15]. In our study, the measurements taken from 32 anatomical points of

Address for correspondence: R. İlgün, PhD, Department of Anatomy, Faculty of Veterinary Medicine, Aksaray University, Aksaray, Turkey, Postal code: 68100, tel: +903822882863, e-mail: rilgun1980@hotmail.com; rilgun2017@gmail.com

This article is available in open access under Creative Common Attribution-Non-Commercial-No Derivatives 4.0 International (CC BY-NC-ND 4.0) license, allowing to download articles and share them with others as long as they credit the authors and the publisher, but without permission to change them in any way or use them commercially. 


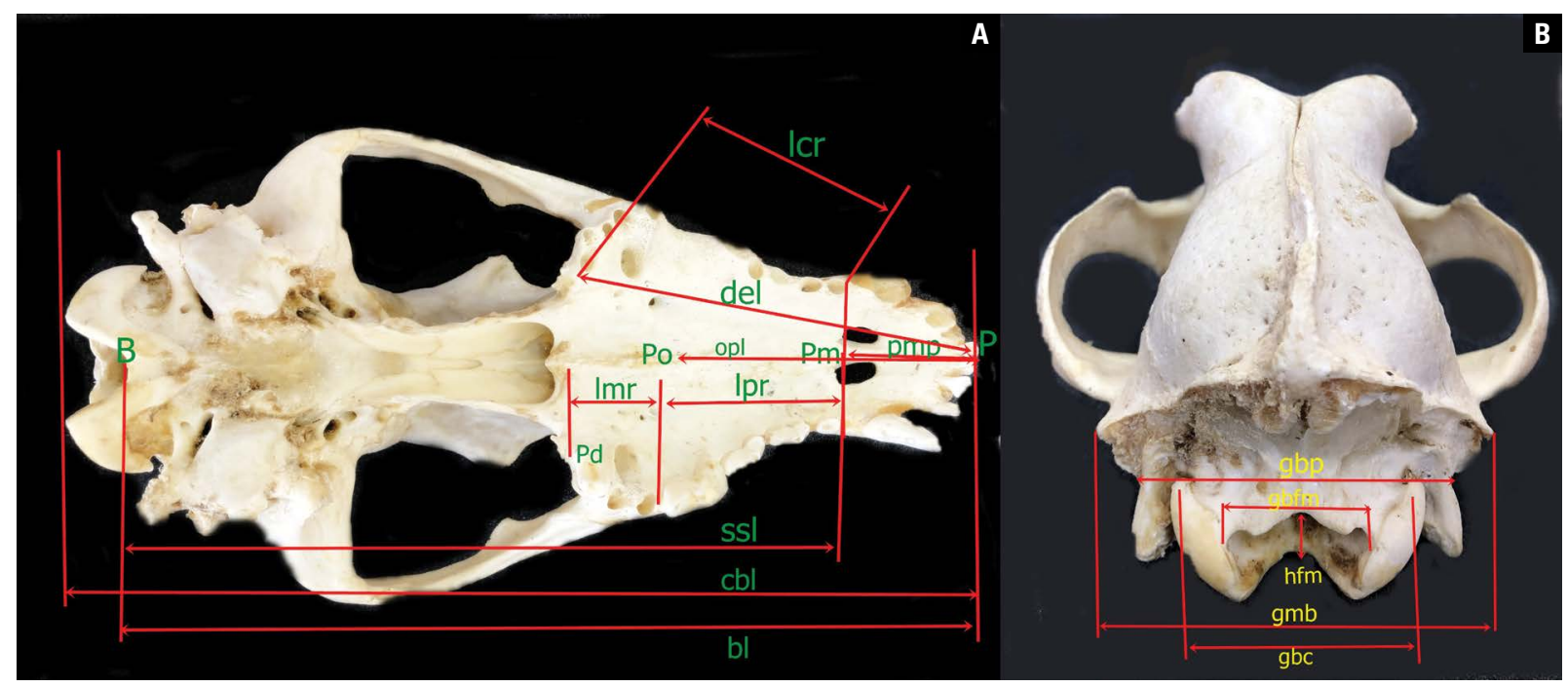

Figure 1. Measurements of the skull of Aksaray Malakli dog; A. Ventral view; B. Caudal view; Akmlk — Aksaray Malakli dog; pl — profile length; $\mathrm{cbl}$ — condylobasal length; $\mathrm{bl}$ — basal length; ssl — short skull length; pmp — premolare-prosthion; $\mathrm{nl}$ — neurocranium length; $\mathrm{vl}$ — viscerocranium length; $\mathrm{mfl}$ - median frontal length; unl — upper neurocranium length; $\mathrm{fcl}$ — facial length; ais — akrokranion-infraorbitale of one side; gll — greatest length of the lacrimal; gln — greatest length of the nasals; slfl — short lateral facial length; fabo — from the aboral border of one occipital condyle to the infraorbitale of the same side; del — dental length; opl — oral palatal length; IIp — lateral length of the premaxilla; Icr — length of the cheektooth row (measured along the alveoli); Imr — length of the molar row (measured along the alveoli on the buccal side); Ipr — length of the premolar row (measured along the alveoli on the buccal side); giho — greatest inner height of the orbit; gmb — greatest mastoid breadth; gbc — greatest breadth of the occipital condyles; gbp — greatest breadth at the bases of the paraoccipital processes; gbfm — greatest breadth of the foramen magnum; hfm — height of the foramen magnum; gncb — greatest neurocranium breadth; lbbo — least breadth between the orbits; gbap — greatest breadth across the premaxillae; infl — distance between two infraorbitals; grpb - greatest palatal breadth.

Aksaray Malakli dog skull bones were compared with other dog breeds by making statistical calculations in line with the literature information. The results of the examination were compared with other carnivores. Significant differences were detected.

The aim of this study was to assess Aksaray Malakli dog skulls morphometrically in detail. By doing so, we hope to contribute to the international morphology database on dog breeds.

\section{MATERIALS AND METHODS}

Sample collection and processing

The skulls of 9 Aksaray Malakli dogs, aged 4-5 years old, regardless of the difference in weight and gender, that had died of various reasons at the Veterinary Health and Practice and Research Centre of Aksaray University Veterinary Faculty between 2015 and 2019, were used in this study.

Skulls were harvested and cleaned according to a standard protocol $[13,24]$. In short, this protocol consisted of boiling the skinned skull in 5-10\% $\mathrm{NaHCO}_{3}$ for 1 day, cleaning from soft tissue manually thereafter, then immersing in a $10 \%$ hydrogen peroxide solution for 2-3 days. Skulls were prepared for measurements after maceration [24].

\section{Morphometry}

In the literature, there are reports on skull measurements. Simoens et al. [23] (Peking dog), Onar [19] (German wolfdog), Onar et al. [21] (Kangal dog) reported measurement locations and methods applied. Of the 44 measurement points reported in the literature [19, 20, 23], 32 measurement points that are prominent in the Aksaray Malakli dog were selected. Thirty-two measurements were made with a digital calliper (A Brand, $200 \mathrm{~mL}$, Germany). Seven index ratios were calculated. The calculation methods used in the Kangal dog morphometry study [21] were applied. One measurement was taken from each skull (Figs. 1, 2). In the measurements, the average of both sides of the skull was taken. Images were taken with a camera (Canon CE500). The nomenclature used in this study is according to Nomina Anatomica Veterinaria [16].

\section{Statistical analysis}

Statistical significance of skull measurements was evaluated. Correlation test was used to determine whether there is a relationship between the variables and if so, in which direction and to what extent. The mean, standard deviation and correlation values of 


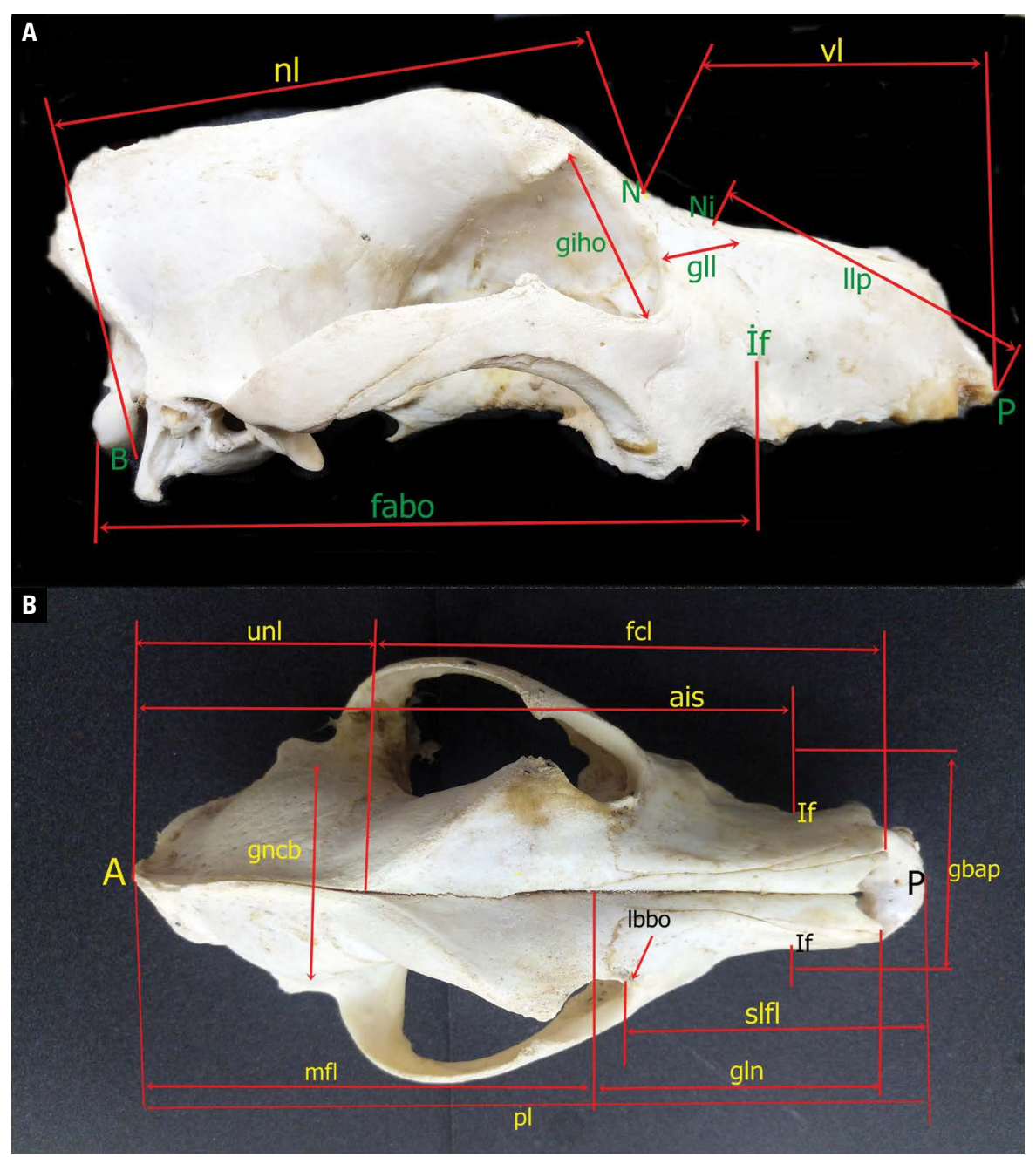

Figure 2. Measurements of the skull of Aksaray Malakli dog; A. Lateral view; B. Dorsal view; abbreviations — see Figure 1.

all measurements obtained were determined in the SPSS (18.0) version programme [6].

\section{RESULTS}

According to the macroanatomical findings in the Aksaray Malakli dog skull, the os frontale and os parietale were prominent. The os temporale was located laterally on the skull bone. The foramen was prominent towards the infraorbital cranial. Tuber faciale was not prominent. Processus zygomaticus of Aksaray Malakli dog was found to be tall and sharp. It was determined that the foramen magnum of os occipitale was surrounded by oval condyli occipitales, and the processi jugulares were curved ventrally. A thick arcus zygomaticus was prominent on the sides of the cranial bones (Figs. 1, 2). The relevant mean and standard deviation values of the craniofacial indices of the Aksaray Malakli dog's skull are shown in Table 1. The calculated cranial indices in Aksaray Malakli dogs were as follows: facial index $107.68 \pm$ \pm 4.98 , nasal index $19.61 \pm 3.25$, cranial index $56.17 \pm$ \pm 2.52 , basal index $30.57 \pm 1.30$, skull index $54.68 \pm$ \pm 3.01 , palatal index $156.76 \pm 1.89$, and palatal index II $59.83 \pm 2.23$. Average and standard deviation values of the Aksaray Malakli dog's skull morphometric parameters are shown in Table 2.

Condylobasal length of Aksaray Malakli dog was $227.03 \pm 12.63 \mathrm{~mm}$, basal length $214.80 \pm 10.93$, neurocranium length $139.43 \pm 3.37 \mathrm{~mm}$, upper neurocranium length $67.66 \pm 13.54 \mathrm{~mm}$, facial length $154.76 \pm 18.48 \mathrm{~mm}$, height of the foramen magnum $20.09 \pm 2.05$. The greatest inner height of the orbit was measured as $37.16 \pm 1.60 \mathrm{~mm}$ (Table 1).

According to the correlation analysis of the Aksaray Malakli dog skull measurements, profile length (pl) and condylobasal length (cbl), short skull length 
Table 1. Craniofacial indices of Aksaray Malakli dog skulls (Akmlk) $(n=9)$

\begin{tabular}{|c|c|c|c|c|c|c|c|}
\hline Akmlk & Facial index & Nasal index & Cranial index & Basal index & Skull index & Palatal index I & Palatal index II \\
\hline Mean \pm SD & $107.68 \pm 4.98$ & $19.61 \pm 3.25$ & $56.17 \pm 2.52$ & $30.57 \pm 1.30$ & $54.68 \pm 3.01$ & $56.76 \pm 1.89$ & $59.83 \pm 2.23$ \\
\hline
\end{tabular}

Table 2. Mean values of 32 morphometric parameters in Aksaray Malakli dog skulls $(n=9)$

\begin{tabular}{|c|c|}
\hline Parameters & Mean \pm SD \\
\hline $\mathrm{pl}$ & $245.78 \pm 15.35$ \\
\hline $\mathrm{cbl}$ & $227.03 \pm 12.63$ \\
\hline bl & $214.80 \pm 10.93$ \\
\hline ssl & $143.95 \pm 22.38$ \\
\hline pmp & $69.17 \pm 14.18$ \\
\hline $\mathrm{nl}$ & $139.43 \pm 3.37$ \\
\hline $\mathrm{vl}$ & $114.39 \pm 3.93$ \\
\hline $\mathrm{mfl}$ & $135.06 \pm 12.55$ \\
\hline unl & $67.66 \pm 13.54$ \\
\hline fcl & $154.76 \pm 18.48$ \\
\hline ais & $177.65 \pm 8.34$ \\
\hline gll & $40.95 \pm 3.79$ \\
\hline$g \mid n$ & $85.74 \pm 5.49$ \\
\hline sifl & $115.67 \pm 4.68$ \\
\hline fabo & $158.95 \pm 7.29$ \\
\hline del & $117.00 \pm 5.97$ \\
\hline Icr & $77.51 \pm 3.73$ \\
\hline Imr & $48.47 \pm 5.19$ \\
\hline Ipr & $36.02 \pm 3,09$ \\
\hline giho & $37.16 \pm 1.60$ \\
\hline gmb & $83.58 \pm 3.68$ \\
\hline$g b c$ & $46.57 \pm 3.79$ \\
\hline gbp & $64.27 \pm 3.90$ \\
\hline $\mathrm{gbfm}$ & $19.88 \pm 2.20$ \\
\hline hfm & $20.09 \pm 2.05$ \\
\hline gncb & $58.36 \pm 3.77$ \\
\hline lbbo & $58,10 \pm 4.54$ \\
\hline gbap & $45.57 \pm 5.20$ \\
\hline infl & $51.74 \pm 4.27$ \\
\hline grpb & $79.78 \pm 4.69$ \\
\hline$\| p$ & $69.66 \pm 8.44$ \\
\hline opl & $110.73 \pm 12.55$ \\
\hline
\end{tabular}

SD — standard deviation; rest abbreviations - see Figure 1

(ssl), facial length (fcl), from the aboral border of one occipital condyle to the infraorbitale of the same side (fabo), basal length (bl), ssl, fcl, length between cbl and bl, upper neurocranium length (unl) and fabo, bl to fabo, premolare-prosthion ( $\mathrm{pmp}$ ) length and oral palatal length (opl), there was a very strong positive correlation between $\mathrm{fcl}$ length and fabo length, neurocranium length ( $\mathrm{nl}$ ) and length of the molar row $(\mathrm{Imr})$, and the greatest breadth across the premaxillae (gbap) and the distance between two infraorbitals (infl). On the other hand, it was found that there is a strong negative correlation between ssl length and pmp length (Table 3).

\section{DISCUSSION}

Atalar et al. [1] reported that the dorsal part of the neurocranium, which forms the skull, consists of frontal and parietal bones in wolves and foxes, and the lateral part of the temporal bone. Similar findings were detected in the Aksaray Malakli dog.

Karan et al. $[11,12]$ reported that foramen infraorbitale was shaped narrow and oval in dogs, and tuber faciale was absent. Similar to the literature [11, 12], there was no tuber faciale in our study, but the foramen infraorbital was in a deep pit.

In the study, the facial index of the Aksaray Malakli dog was found to be $107.68 \pm 4.98$. The facial index was reviewed in literature reviews in collie $[8,21]$ and Russian wolfhound dogs $[8,21]$ at 81 , in German shepherd $[8,21]$, beagle $[8,21]$ and setter $[8,21]$ dogs at 111 , and in Boston terrier $[8,21]$ and Pekingese dogs $[8,21]$ at 215 . The facial index of Aksaray Malakli dog according to index values that of collie $[8,21]$, Russian wolfhound $[8,21]$, German shepherd [8, 21], beagle $[8,21]$ and setter $[8,21]$, and lower than that of Boston terrier $[8,21]$ and Pekingese $[8,21]$ dogs.

In our study, the cranial index value of Aksaray Malakli dog was $56.17 \pm 2.52$. It was reported at 48 in Collie and Russian wolfhound, 57 in German shepherd, beagle and setter dogs, and 81 in Boston terrier and Pekingese dogs $[8,21]$. It was calculated as 73.24 in German wolfdog [20] and 71.28 in golden jackal [15]. Cranial index value of Aksaray Malakli dog was higher than that of collie $[8,21]$ and Russian wolfhound $[8,21]$ dogs, German wolfdog [19], golden jackal [15], German shepherd [8, 21], and 
Table 3. Correlation values of different skull measurements in the Aksaray Malakli dog $(n=9)$

\begin{tabular}{|c|c|c|c|c|c|c|c|c|c|c|c|}
\hline \multirow[t]{18}{*}{ pl } & $\mathrm{cbl}$ & $0.948 * * *$ & bl & ssl & $0.852^{*}$ & $\mathrm{mfl}$ & unl & $0.840^{*}$ & fcl & ais & $0.890^{* *}$ \\
\hline & $\mathrm{bl}$ & $0.956^{* * *}$ & & $\mathrm{vl}$ & $0.779 *$ & & $\mathrm{fcl}$ & $0.916^{* *}$ & & fabo & $0.970^{* * *}$ \\
\hline & ssl & $0.962^{* * *}$ & & $\mathrm{mfl}$ & $0.814^{*}$ & & ais & $0.972^{* * *}$ & & del & $0.765^{*}$ \\
\hline & $\mathrm{pmp}$ & $-0.784^{*}$ & & unl & $0.914^{* *}$ & & fabo & $0.853^{*}$ & & opl & $-0.784^{*}$ \\
\hline & $\mathrm{mfl}$ & $0.927^{* *}$ & & $\mathrm{fcl}$ & $0.949 * *$ & & opl & $-0.874^{* *}$ & & giho & $0.904^{* *}$ \\
\hline & unl & $0.919^{* *}$ & & ais & $0.822^{*}$ & & giho & $0.788^{*}$ & & gmb & $0.904^{* *}$ \\
\hline & $\mathrm{fcl}$ & $0.994 * * *$ & & gln & $-0.779^{*}$ & & gmb & $0.763^{*}$ & & $g b c$ & $0.891^{* *}$ \\
\hline & ais & $0.907^{* *}$ & & fabo & $0.949 * * *$ & ais & fabo & $0.850^{*}$ & & $\mathrm{gbfm}$ & $0.793^{*}$ \\
\hline & gln & $-0.786^{*}$ & & del & $0.904^{* *}$ & & opl & $-0.817^{*}$ & & gbap & $0.787^{*}$ \\
\hline & fabo & $0.972^{* * *}$ & & giho & $0.943^{* *}$ & & giho & $0.771^{*}$ & & infl & $0.889 * *$ \\
\hline & del & $0.777^{*}$ & & gmb & $0.955^{* *}$ & & gmb & $0.770^{*}$ & gbfm & $\mathrm{hfm}$ & $0.872^{* *}$ \\
\hline & opl & $-0.795^{*}$ & & $g b c$ & $0.931^{* *}$ & gln & fabo & $-0.794^{*}$ & & gncb & $0.829 *$ \\
\hline & giho & $0.888^{* *}$ & & gbp & $0.899^{* *}$ & & gncb & $-0.849^{*}$ & & infl & $0.757^{*}$ \\
\hline & gmb & $0.901^{* *}$ & & $\mathrm{gbfm}$ & $0.789 *$ & & gbap & $-0.822^{*}$ & del & Icr & $0.901^{* *}$ \\
\hline & $g b c$ & $0.872^{*}$ & & gbap & $0.796^{*}$ & slfi & Icr & $0.755^{*}$ & & Ipr & $0.822^{*}$ \\
\hline & $\mathrm{gbfm}$ & $0.790^{*}$ & & infl & $0.873^{* *}$ & & Ipr & $0.797^{*}$ & & giho & $0.853^{*}$ \\
\hline & gbap & $0.779 *$ & pmp & $\mathrm{NI}$ & $0.834^{*}$ & & grpb & $0.901^{* * *}$ & & gmb & $0.856^{*}$ \\
\hline & infl & $0.863^{*}$ & & $\mathrm{mfl}$ & $-0.782^{*}$ & fabo & del & $0.810^{*}$ & & $g b c$ & $0.782^{*}$ \\
\hline \multirow[t]{17}{*}{ cbl } & $\mathrm{bl}$ & $0.980^{* * *}$ & & $\mathrm{Fcl}$ & $-0.771^{*}$ & & giho & $0.853^{*}$ & & gbp & $0.848^{*}$ \\
\hline & ssl & $0.850^{*}$ & & opl & $0.963^{* * *}$ & & gmb & $0.846^{*}$ & & gbap & $0.773^{*}$ \\
\hline & $\mathrm{vl}$ & $0.838^{*}$ & & Llp & $0.926^{* *}$ & & $\mathrm{gbc}$ & $0.897^{* *}$ & & infl & $0.791^{*}$ \\
\hline & $\mathrm{mfl}$ & $0.822^{*}$ & & Imr & $0.912^{* *}$ & & gbp & $0.763^{*}$ & $\mathrm{nl}$ & opl & $0.784^{*}$ \\
\hline & unl & $0.966^{* * *}$ & & $\mathrm{hfm}$ & $-0.824^{*}$ & & gbap & $0.840^{*}$ & & $\| p$ & $0.862^{*}$ \\
\hline & $\mathrm{fcl}$ & $0.955^{* *}$ & ssl & $\mathrm{pmp}$ & $-0.920^{* *}$ & & infl & $0.886^{* *}$ & & Imr & $0.982^{* * *}$ \\
\hline & ais & $0.836^{*}$ & & $\mathrm{mfl}$ & $0.912^{* *}$ & Ipr & giho & $0.759^{*}$ & $\mathbf{v l}$ & unl & $0.763^{*}$ \\
\hline & fabo & $0.966^{* * *}$ & & unl & $0.858^{*}$ & & $\mathrm{gbc}$ & $0.797^{*}$ & & $\mathrm{fcl}$ & $0.802^{*}$ \\
\hline & del & $0.905^{* *}$ & & $\mathrm{Fcl}$ & $0.955^{* *}$ & & lbbo & $0.767^{*}$ & & Icr & $0.840^{*}$ \\
\hline & Icr & $0.823^{*}$ & & ais & $0.882^{* *}$ & & gbap & $0.847^{*}$ & & Ipr & $0.887^{* *}$ \\
\hline & Ipr & $0.819^{*}$ & & gln & $-0.802^{*}$ & & infl & $0.891^{* *}$ & & giho & $0.879 * *$ \\
\hline & giho & $0.945^{* *}$ & & fabo & $0.939 * *$ & & grpb & $0.759^{*}$ & & gmb & $0.841^{*}$ \\
\hline & gmb & $0.915^{* *}$ & & opl & $-0.905^{* *}$ & giho & gmb & $0.947^{* * *}$ & & $\mathrm{gbc}$ & $0.812^{*}$ \\
\hline & $g b c$ & $0.925^{* *}$ & & Imr & $-0.755^{*}$ & & $g b c$ & $0.910^{* *}$ & & infl & $0.886^{* *}$ \\
\hline & gbp & $0.837^{*}$ & & gmb & $0.781^{*}$ & & gbp & $0.859^{*}$ & $\| p$ & Imr & $0.935^{* *}$ \\
\hline & gbap & $0.816^{*}$ & & $\mathrm{gbc}$ & $0.771^{*}$ & & infl & $0.814^{*}$ & hmf & gncb & $0.843^{*}$ \\
\hline & infl & $0.898^{* *}$ & & $\mathrm{hfm}$ & $0.762^{*}$ & gmb & $\mathrm{gbc}$ & $0.889^{* *}$ & gncb & gbap & $0.756^{*}$ \\
\hline \multirow[t]{4}{*}{ Icr } & Ipr & $0.937^{* *}$ & & gbap & $0.779 *$ & & gbp & $0.866 *$ & lbbo & gbap & $0.862^{*}$ \\
\hline & giho & $0.797^{*}$ & & infl & $0.827^{*}$ & & $\mathrm{gbfm}$ & $0.869^{*}$ & gbap & infl & $0.953^{* * *}$ \\
\hline & infl & $0.773^{*}$ & opl & Llp & $0.898^{* *}$ & & gbap & $0.762^{*}$ & & & \\
\hline & grpb & $0.760^{*}$ & & Imr & $0.877^{* *}$ & & infl & $0.877^{* *}$ & & & \\
\hline
\end{tabular}

Abbreviations - see Figure 1; ${ }^{*} p<0.05,{ }^{* *} p<0.01,{ }^{* * *} p<0.001$

beagle $[8,21]$. It was observed to be lower than setter $[8,21]$, Boston terrier $[8,21]$ and Pekingese $[8,21]$ dogs.

Khosravi et al. [14] reported basal index value in grey wolf was $60.56 \pm 3.99$ and cranial index value was $60.66 \pm 2.94$, whereas Onar et al. [22] evaluated basal index value in red foxes as 37.75 and 35.34 , and cranial index value as 62.37 and 57.92. It was observed in our Aksaray Malakli dog that the basal index value 
was $30.57 \pm 1.30$ and the cranial index value was $56.17 \pm 2.52$ - lower than grey wolf [14] and red fox [22].

Onar et al. [21] reported the skull index value as 64.00 in husky du labrador dog, 63.00 in pointer dog, 60.17 in St. Bernard dog, and Khosravi et al. [2012] as $53.13 \pm 3.35$ in grey wolf. In another study, it was reported that in red foxes [22] it was calculated as 52.52 and 52.53. The skull index value of Aksaray Malakli dog was found to be $54.68 \pm 3.01$ - higher than that of grey wolf [14] and red fox [22] while it was lower than husky du labrador dog, pointer dog and St. Bernard dog [21].

Onar et al. [22] evaluated the palatal index I value as 56.52 and 54.11, and the palatal index II value as 57.95 and 55.10 in their study in red foxes. The palatal index I value of Aksaray Malakli dog was $56.76 \pm 1.89$, and the palatal index II value was $59.83 \pm 2.23$ - higher than red foxes.

In the literature studies, condylobasal length measurement was reported as $215.76 \pm 12.22$ in grey wolf [14], basal length measurement was $206.79 \pm$ $\pm 11.13 \mathrm{~mm}$, and in this study, condylobasal length of Aksaray Malakli dog was $227.03 \pm 12.63 \mathrm{~mm}$ and basal length value was $214.80 \pm 10$. According to these evaluations, the condylobasal length and basal length of Aksaray Malakli dog was longer than that of grey wolf [14].

In the study, the length of neurocranium in Aksaray Malakli dog was determined as $139.43 \pm 3.37 \mathrm{~mm}$. This measurement value was reported to be $74.21 \pm$ \pm 8.91 in grey wolf [14]. According to the measurement values, it was determined that the length of neurocranium of Aksaray Malakli dog was longer than that of grey wolf [14].

In the skulls of the Aksaray Malakli dog examined, the upper neurocranium length was $67.66 \pm 13.54 \mathrm{~mm}$. In the literature studies, upper neurocranium length measurement was reported to be $58.56 \pm 5.99 \mathrm{~mm}$ in grey wolf [14]. Our investigation material revealed that Aksaray Malakli dog's upper neurocranium length is longer than grey wolf [14].

İlgün and Özkan [10] reported greatest inner height of the orbit as $31.06 \pm 1.15 \mathrm{~mm}$ in Kangal dog. In our research material of Aksaray Malakli dog, this height was measured as $37.16 \pm 1.60 \mathrm{~mm}$. According to the measurement values, the greatest inner height of the orbit of the Aksaray Malakli dog was longer than the Kangal dog [10].
In our study, the height of the foramen magnum of Aksaray Malakli dog was measured as $20.09 \pm$ $\pm 2.05 \mathrm{~mm}$. In the study of Iilgün and Özkan [10] on Kangal dog, the height of the foramen magnum is reported as $24.86 \pm 0.59 \mathrm{~mm}$. The height of the foramen magnum of Aksaray Malakli dog was found to be shorter than the Kangal dog.

\section{CONCLUSIONS}

According to the results of the study, it is thought that the skull measurements and index calculations of Aksaray Malakli dog will contribute to the creation of a databank in racial discrimination. It is also thought to provide resources for specialists working in different disciplines such as anatomy, morphology, osteo-archeology and can be used in determining the taxonomic classification of carnivorous species. However, it was concluded that more sample studies are needed to obtain more absolute data on the relationships between statistical parameters.

\section{Conflıct of interest: None declared}

\section{REFERENCES}

1. Atalar Ö, Üstündağ Y, Yaman M, et al. Comparative anatomy of the neurocranium in some wild carnivora. J Anim Vet Adv. 2009; 8: 1542-1544.

2. Atasoy F, Kanlı O. Türk çoban köpeği kangal. 2. Baskı, Ankara. Medisan Yayınevi, 2005. No: 60.

3. Atasoy F, Uğurlu M, Özarslan B, et al. Halk elinde yetiştirilen Akbaş köpeklerinde canlı ağırlık ve vücut ölçüleri. Ankara Univ Vet Fak Derg. 2011; 58(3): 213-215, doi: 10.1501/ vetfak_0000002477.

4. Atasoy F. Türk Mastifi Köpeklerin morfolojik ve genetik özelliklerinin belirlenmesi ve bu köpeğin Tanıtılması. 1.Baskı, Ankara: Medisan Matbaacılık 2011.

5. Atasoy F, Erdoğan M, Özarslan F, et al. Malaklı Karabaş köpeklerde bazı morfolojik ve genetik özellikler. Ankara Üniv Vet Fak Derg. 2014; 61(2): 125-132, doi: 10.1501/ vetfak_0000002616.

6. Büyüköztürk Ş. Sosyal Bilimlerde Veri Analizi El Kitabı. Pegem Yayınevi, Ankara 2011.

7. Dayan MO, Gürbüz i, Demiraslan Y, et al. Craniometric Measurements of the Male Eurasian Lynx from Turkey. Anim Vet Sci. 2017; 5(1): 15, doi: 10.11648/j. avs.20170501.13.

8. Evans HE, Christensen GC. The skeletal system [skull]. In: Miller's Anatomy of the Dog. Evans HE ed. 3rd ed. Chapter 1. W.B. Saunders, Philadelphia 1993: 6-49.

9. Figueirido B, Pérez-Claros J, Hunt R, et al. Body mass estimation in amphicyonid carnivoran mammals: a multiple regression approach from the skull and skeleton. Acta Palaeontologica Polonica. 2011; 56(2): 225-246, doi: 10.4202/app.2010.0005. 
10. İlgün R, Özkan ZE. Aksaray Malaklı Köpeği ile Kangal Köpeği Neurocranium ve Splanchnocranium Kemiklerinin Bazı Osteometrik Ölçümlerinin Karşılaştırılmalı Olarak Incelenmesi. F Ü Sağ Bil Vet Derg. 2015; 29: 157-161.

11. Karan M, Aydın A, Timurkaan S, et al. Bazı carnivorlarda viscerocranium'un karşılaştırmalı makroanatomik incelenmesi. F Ü Sağ Bil Vet Derg. 2015; 19: 99-102.

12. Karan M, Timurkaan S, Ozdemir D, et al. Comparative macroanatomical study of the neurocranium in some carnivora. Anat Histol Embryol. 2006; 35(1): 53-56, doi: 10.1111/j.14390264.2005.00659.x, indexed in Pubmed: 16433674.

13. Keneisenuo K, Choudhary OP, Priyanka P, et al. Applied anatomy and clinical significance of the maxillofacial and mandibular regions of the barking deer (Muntiacus muntjak) and sambar deer (Rusa unicolor). Folia Morphol. 2021; 80(1): 170-176, doi: 10.5603/FM.a2020.0061, indexed in Pubmed: 32491187.

14. Khosravi R, Kaboli M, Imani J, et al. Morphometric variations of the skull in the Gray Wolf (Canis lupus) in Iran. Acta Theriologica. 2012; 57(4): 361-369, doi: 10.1007/ s13364-012-0089-6.

15. Monfared AL. Macroanatomical investigation of the skull of Golden Jackal [Canis aureus] and its clinical Application during Regional Anethesia. Global Veterinaria. 2013; 10: 547-550, doi: 10.5829/idosi.gv.2013.10.5.7298.

16. Nomina Anatomica Veterinaria [NAV]. International Comitte on Veterinary Gross Anatomical Nomenclature. General assembly of the World Association of Veterinary Anatomists. Fifth Edition Gent. Published by the Editorial Committee Hannover [Germany] Columbia. MO [U.S.A.] Ghent [Belgium]. Sapporo [Japan]. 2012.

17. Oğrak $Y$, Yoldaş $A$, Uroseviç $M$, et al. Some morphological traits of Tarsus Çatalburun breed of Turkish hunting dog. Eurasian J Vet Sci. 2014; 30(1): 25-25, doi: 10.15312/ eurasianjvetsci.201415912.
18. Oğrak $Y$, Öztürk N, Akın D, et al. Comparison various body measurements of Aksaray Malakli and Kangal Dogs. J Istanbul Vet Sci. 2018; 2(3): 86-91, doi: 10.30704/httpwww-jivs-net.462546.

19. Onar V. A morphometric study on the skull of the German shepherd dog (Alsatian). Anat Histol Embryol. 1999; 28(4): 253-256, doi: 10.1046/j.1439-0264.1999.00202.x, indexed in Pubmed: 10488631.

20. Onar V, Kahvecioğlu KO, Mutuş R, et al. Alman Kurt Köpeklerinde Mandibulanın Morfometrik Analizi [Morphometric Analysis Of The Mandible In German shepherd Dogs]. Vet Anim Sci. 1999; 23: 329-334.

21. Onar V, Pazvant S, Özcan S. Skull typology of adult male Kangal dogs. Anat Histol Embryol. 2001; 30(1): 41-48, doi: 10.1046/j.1439-0264.2001.00292.x.

22. Onar V, Belli O, Owen P. Morphometric examination of red fox (vulpes vulpes) from the van-yoncatepe necropolis in Eastern Anatolia. Int J Morphol. 2005; 23(3), doi: 10.4067/ s0717-95022005000300011.

23. Simoens $P$, Poels $P$, Lauwers $H$. Morphometric analysis of the foramen magnum in Pekingese dogs. Am J Vet Res. 1994; 55(1): 34-39, indexed in Pubmed: 8141494.

24. Taşbaş $M$, Tecirlioğlu $S$. Maserasyon tekniği üzerinde araştırmalar. J Faculty Vet Med. 1966; 12: 324-30.

25. Tserendorj M, Reading RP, Buuveibaatar B, et al. Comparative Craniometric Measurements of Two Sympatric Species of Vulpes in Ikh Nart Nature Reserve, Mongolia. Mongol J Biol Sci. 2018; 18(1), doi: 10.22353/mjbs.2018.16.03.

26. Yılmaz O. Türk kangal [Karabaş] Köpeği 4.Baskı. İstanbul: Bilge Kültür Sanat Yayınevi. 2018.

27. Yılmaz O, Ertuğrul M. Türkiye yerli köpek ırk ve tipleri. Igdır Univ J Ins Sci Tech. 2012; 02: 99-106.

28. Zinoviev AV. Study of the medieval dogs from novgorod, Russia (X-XIV century). Int J Osteoarchaeol. 2010; 22(2): 145-157, doi: 10.1002/oa.1191. 